\title{
Phytotherapeutic practices of a folk medicinal practitioner in Dinajpur district, Bangladesh
}

\author{
Rifat Shah, Maidul Islam, Fazlay Rabbi, Nasrin Akter Shova, Aysha Akter, Hasna Akter, Istieake Ahmed, \\ Erena Islam, Mohammed Rahmatullah* \\ Department of Pharmacy, University of Development Alternative, Lalmatia, Dhaka-1207, Bangladesh.
}

\begin{tabular}{|c|c|}
\hline ARTICLE INFO & ABSTRACT \\
\hline Article history: & \multirow{7}{*}{$\begin{array}{l}\text { The phytotherapeutic practices of a folk medicinal practitioner (FMP), practicing in Kaliaganj village of } \\
\text { Dinajpur district, Bangladesh, was documented. Interviews of the FMP were carried out with the help of a semi- } \\
\text { structured questionnaire and guided field-walk method. The FMP was observed to use a total of } 48 \text { plants } \\
\text { distributed into } 36 \text { families for treatment of diverse diseases, which included respiratory tract disorders, } \\
\text { gastrointestinal disorders, skin disorders, leucorrhea, urinary disorders, menstrual disorders, physical weakness, } \\
\text { edema, Parkinson's disease (body tremors), piles, bleeding through anus or penis, stone in urinary tract, and } \\
\text { bone fracture. Most of the formulations used to treat diseases consisted of more than one plant species. Taken } \\
\text { together, most of the formulations appeared to be quite different from plant formulations used by other FMPs in } \\
\text { Dinajpur district as well as other places of Bangladesh (as observed in our previous field observations) and as } \\
\text { such merit further research towards discovery of new drugs. }\end{array}$} \\
\hline Received on: $21 / 11 / 2016$ & \\
\hline Accepted on: 03/03/2017 & \\
\hline Available online: $30 / 05 / 2017$ & \\
\hline Key words: & \\
\hline Ethnomedicine, Kaliaganj, & \\
\hline Dinajpur, Bangladesh. & \\
\hline
\end{tabular}

\section{INTRODUCTION}

Bangladesh is a country of diverse traditional medicinal systems. The more established ones are Ayurveda, Unani and homeopathy. However, besides the above three, there are other forms of traditional medicines, the major two being folk medicine and tribal medicine. The latter can be considered also as a variation of folk medicine, being practiced by various tribes instead of mainstream Bengali-speaking practitioners, who practice folk medicine. Folk medicinal practitioners (FMPs) possibly constitute the largest group of medicinal practitioners and can be found in every village, town and city of the country. Anybody (both male and female and of any occupation and age) can practice folk medicine, for the practitioners do not need to attend any learning institutions or be registered with the Government. While this has given rise among FMPs of quacks and charlatans, surprisingly many FMPs can be found with a

* Corresponding Author

E-mail: rahmatm @ uoda.edu.bd large clientele, established practices, and a good knowledge of medicinal properties of plants.

Considerable knowledge can be obtained from systematic surveys conducted among FMPs on medicinal plants of the country. Plants have always formed an excellent source for medicines since ancient times, and FMPs usually use plants for therapeutic purposes. This traditional knowledge, in turn, can form the basis for further research leading to new drug discoveries. The discovery of new drugs is a necessity because of the emergence of new diseases and existing drug-resistant vectors. We had been conducting ethnomedicinal surveys among different FMPs and tribal medicinal practitioners of the country (Rahmatullah and Biswas, 2012; Rahmatullah et al., 2012a-c; Zaman et al., 2015; Kundu et al., 2016). During our surveys, it was observed that considerable variation exists among the FMPs on diseases treated and the plants used for treating even the same disease. These variations can be observed within FMPs of the same village and which pointed out the necessity of documenting the practices of as many FMPs as possible from all parts of the country to obtain a comprehensive idea of the medicinal plants of the country. 
More surprisingly, it was observed that many of the plants used by the FMPs can be validated in their uses based on their reported pharmacological properties in the existing scientific literature. The objective of the present study was to document the phytotherapeutic practices of a FMP practicing in Kaliaganj village in Dinajpur district, Bangladesh.

\section{MATERIALS AND METHODS}

The FMP who was interviewed was named Abdul Bareque (male, age 70 years, practicing folk medicine for 40 years), and resided in the village of Kaliaganj in Dinajpur district, Bangladesh. Prior informed consent was initially obtained from the FMP. The FMP was informed as to the nature of our visit and consent obtained to disseminate any information provided including his name both nationally and internationally.

Actual interviews were conducted in the Bengali language, which was spoken fluently by the FMP as well as the interviewers. The interviews were conducted with the help of a semi-structured questionnaire and the guided field-walk method of Martin (1995) and Maundu (1995). In this method the FMP took the interviewers on guided field-walks through areas from where he collected his medicinal plants or plant parts, pointed out the plants, and described their uses. All plant specimens were photographed and collected on the spot, pressed, dried and brought back to be identified by a competent botanist at the University of Development Alternative. Some specimens were also identified at the Bangladesh National Herbarium. Voucher specimens were deposited with the Medicinal Plant Collection Wing of the University of Development Alternative. The authors are grateful to the Ethics and Publication Committee, University of Development Alternative for approval of the survey.

\section{RESULTS AND DISCUSSION}

The FMP was observed to use a total of 48 plants distributed into 36 families for treatment of diverse diseases, which included respiratory tract disorders, gastrointestinal disorders, skin disorders, leucorrhea, urinary disorders, menstrual disorders, physical weakness, edema, Parkinson's disease (body tremors), piles, bleeding through anus or penis, stone in urinary tract, and bone fracture. Most of the formulations used to treat diseases consisted of more than one plant species. The results are shown in Table 1. Most of the formulations appeared to be quite distinct from formulations obtained in our previous ethnobotanical surveys. Some of the plants and formulations used by the FMP merits attention and discussion. Justicia adhatoda was used with Ocimum tenuiflorum and Zingiber officinale by the FMP to treat coughs. The anti-tussive action of a polyherbal formulation containing J. adhatoda has been described (Gupta et al., 2009). Interestingly, the formulation also contained Ocimum sanctum (synonym of Ocimum tenuiflorum). Z. officinale is used in Ayurveda to treat coughs and as such has a long history of use for cough treatment (Malhotra and Singh 2003). Thus the three plant species used by the FMP to treat coughs are valid in their uses. In fact, the three plant species can give potentially a powerful synergistic action in cough treatment.

For treatment of dysentery, the FMP used another polyherbal formulation where barks of Holarrhena pubescens (also known as Holarrhena antidysenterica), Spondias pinnata, Alstonia scholaris and Syzygium cumini were soaked together in water overnight followed by drinking the water on an empty stomach the following morning. The antidiarrheal action of $H$. antidysenterica has been shown in rats (Sharma et al., 2015). The bark of $A$. scholaris can reportedly inhibit some enteric pathogens and so can be useful in treating dysentery (Mukherjee et al., 2012). The barks of $S$. pinnata and S. cumini merit scientific research regarding their anti-dysentery actions, for although not studied scientifically, indigenous uses of the plants for treatment of diarrhea and dysentery has been reported (Bora et al., 2014; Ayyanar and Subash-Babu, 2012).

The other polyherbal formulations of the FMP deserve scientific research, particularly the formulations for treatment of asthma and Parkinson's disease. Polyherbal formulations are regarded as being more effective in the sense that in some cases the plants can act synergistically and so produce a more powerful effect, and in other cases the toxic effect of any particular plant may be negated through the use of a second plant leaving only the desirable effect of the first plant to have its action. Asthma is difficult to control and Parkinson's disease has no known cure in allopathic medicine. That the FMP was treating Parkinson's disease was confirmed by the patient whose disease was diagnosed in a modern clinic by allopathic doctors, whose medicines, however, did not have any positive effects on the patient leaving him to seek the FMPs cure. As such, a real cure of Parkinson's disease from the FMPs formulation, as validated by modern research, can be of huge benefit to human beings.

Table 1: Plants and formulations of the FMP from Kaliaganj village in Dinajpur district, Bangladesh.

\begin{tabular}{cllccl}
\hline $\begin{array}{c}\text { Serial } \\
\text { Number }\end{array}$ & Scientific Name & Family Name & Local Name & Parts used & Ailments and mode of medicinal use \\
\hline 1 & $\begin{array}{l}\text { Justicia adhatoda } \\
\text { (L.) Nees }\end{array}$ & Acanthaceae & Bashok & Leaf & $\begin{array}{l}\text { Coughs. Juice obtained from leaves of Justicia adhatoda } \text { and } \\
\text { leaves of Ocimum tenuiflorum and rhizomes of Zingiber } \\
\text { officinale is mixed with } 3 \text { drops of honey and taken orally. } \\
\text { See Alocasia indica. }\end{array}$ \\
\hline 2 & Mangifera indica L. & Anacardiaceae & Aam & Seed & See Salmalia malabarica. \\
\hline 3 & $\begin{array}{l}\text { Spondias pinnata } \\
\text { (L.f.) Kurz }\end{array}$ & Anacardiaceae & Amra & Bark & See Holarrhena pubescens. \\
\hline
\end{tabular}




\begin{tabular}{|c|c|c|c|c|c|}
\hline 4 & $\begin{array}{l}\text { Alstonia scholaris } \\
\text { (L.) R.Br. }\end{array}$ & Apocynaceae & Chaitan & Bark & See Holarrhena pubescens. \\
\hline 5 & $\begin{array}{l}\text { Holarrhena } \\
\text { pubescens Wall. } \\
\text { ex G. Don }\end{array}$ & Apocynaceae & Indrajol & Bark & $\begin{array}{l}\text { Dysentery. Barks of Holarrhena pubescens, Spondias pinnata, Alstonia } \\
\text { scholaris and Syzygium cumini are soaked together in water overnight } \\
\text { followed by drinking the water on an empty stomach the following } \\
\text { morning. }\end{array}$ \\
\hline 6 & $\begin{array}{l}\text { Alocasia indica } \\
\text { (Roxb.) Schott }\end{array}$ & Araceae & Maan kochu & Tuber & $\begin{array}{l}\text { Asthma. Tubers of Alocasia indica are powdered with leaves of Justicia } \\
\text { adhatoda, whole plants of Plumbago zeylanica, and whole plants of } \\
\text { Nicotiana tabacum and mixed with honey. Pills prepared from the } \\
\text { mixture are dried under the sun. The pills are then coated with ghee } \\
\text { (clarified butter) and taken orally. }\end{array}$ \\
\hline 7 & $\begin{array}{l}\text { Colocasia } \\
\text { esculenta }(\mathrm{L} .) \\
\text { Schott }\end{array}$ & Araceae & Mokoddos & Tuber & See Carthamus tinctorius. \\
\hline 8 & Cocos nucifera $\mathrm{L}$. & Arecaceae & Narikel & Oil & See Wedelia chinensis. \\
\hline 9 & $\begin{array}{l}\text { Sansevieria } \\
\text { trifasciata } \text { Prain }\end{array}$ & Asparagaceae & $\begin{array}{c}\text { Boro } \\
\text { chokkor }\end{array}$ & Leaf & $\begin{array}{l}\text { Skin disease. Leaf paste is mixed with mustard oil (oil obtained from } \\
\text { seeds of Brassica nigra) and topically applied. }\end{array}$ \\
\hline 10 & $\begin{array}{l}\text { Aloe barbadensis } \\
\text { Mill. }\end{array}$ & Asphodelaceae & Musabbar & Leaf & $\begin{array}{l}\text { Bloating. Leaf pulp of Aloe barbadensis is mixed with tuber paste of } \\
\text { Ipomoea digitata followed by preparation of pills from the mixture. Pills } \\
\text { are taken orally. Note that the pills cannot be taken by anybody under } 12 \\
\text { years of age. Pregnant women should take the pills only after a heavy } \\
\text { meal. }\end{array}$ \\
\hline 11 & $\begin{array}{l}\text { Carthamus } \\
\text { tinctorius } \mathrm{L} .\end{array}$ & Asteraceae & $\begin{array}{c}\text { Kusum } \\
\text { phool }\end{array}$ & Flower & $\begin{array}{l}\text { Leucorrhea, burning sensations during urination, loss of appetite, } \\
\text { physical weakness, irregular menstruation, whitish discharge during } \\
\text { urination. Flowers of Carthamus tinctorius, fruits of Piper cubeba, } \\
\text { flowers of Leea macrophylla, leaves of Piper betle, seeds of Nigella } \\
\text { sativa, seed coat of Myristica fragrans, and tubers of Colocasis } \\
\text { esculenta are combined and cooked to make 'halwa' which is taken } \\
\text { orally twice daily in the morning and evening. }\end{array}$ \\
\hline 12 & $\begin{array}{l}\text { Wedelia chinensis } \\
\text { (Osbeck) Merr. }\end{array}$ & Asteraceae & Bhimraj & Root & $\begin{array}{l}\text { Memory enhancer. Paste of root of Wedelia chinensis and tuber of } \\
\text { Ipomoea digitata is taken orally with raw cow milk or molasses. } \\
\text { Skin infections. A mixture of powdered whole plants of Wedelia } \\
\text { chinensis, powdered roots of Leea macrophylla, and powdered roots of } \\
\text { Trewia polycarpa are combined with warm coconut oil (oil obtained } \\
\text { from fruits of Cocos nucifera) and applied topically to infected area } \\
\text { following cleaning the area. }\end{array}$ \\
\hline 13 & $\begin{array}{l}\text { Brassica nigra } \\
\text { (L.) W.D.J. Koch }\end{array}$ & Brassicaceae & Shorisha & Seed & See Sansevieria trifasciata. \\
\hline 14 & $\begin{array}{l}\text { Terminalia } \\
\text { bellirica (Gaertn.) } \\
\text { Roxb. }\end{array}$ & Combretaceae & Bohera & Fruit & See Salmalia malabarica. \\
\hline 15 & $\begin{array}{l}\text { Terminalia } \\
\text { chebula } \text { Retz. }\end{array}$ & Combretaceae & Hortoki & Fruit & See Salmalia malabarica. \\
\hline 16 & $\begin{array}{l}\text { Ipomoea digitata } \\
\text { L. }\end{array}$ & Convolvulaceae & Bhui kumra & Tuber & $\begin{array}{l}\text { See Wedelia chinensis. } \\
\text { See Aloe barbadensis. } \\
\text { See Salmalia malabarica. }\end{array}$ \\
\hline 17 & $\begin{array}{l}\text { Trewia polycarpa } \\
\text { Benth. }\end{array}$ & Euphorbiaceae & Mudda gach & Root & See Wedelia chinensis. \\
\hline 18 & $\begin{array}{l}\text { Tamarindus indica } \\
\text { L. }\end{array}$ & Fabaceae & Tetul & Leaf & $\begin{array}{l}\text { Mucus in children. One handful of leaf of Tamarindus indica and sliced } \\
\text { fruits of Citrus aurantium are added to water along with a small amount } \\
\text { of sliced rhizome of Zingiber officinale. The water is then boiled till it } \\
\text { reaches half the original volume. The water is then strained and sugar } \\
\text { dissolved in it and re-boiled till the volume is reduced by half. The } \\
\text { decoction is kept in an open jar and taken orally thrice daily. }\end{array}$ \\
\hline 19 & $\begin{array}{l}\text { Ocimum } \\
\text { tenuiflorum } \mathrm{L} .\end{array}$ & Lamiaceae & Tulshi & Leaf & See Justicia adhatoda. \\
\hline 20 & Vitex negundo L. & Lamiaceae & Nishinda tita & Leaf & Edema. Leaf paste is applied topically to swollen areas. \\
\hline 21 & $\begin{array}{l}\text { Cinnamomum } \\
\text { camphora (L.) J. } \\
\text { Presl. }\end{array}$ & Lauraceae & Kofur & Wood & See Sterculia urens. \\
\hline 22 & $\begin{array}{l}\text { Salmalia } \\
\text { malabarica }(\text { DC.) } \\
\text { Schott \& Endl. }\end{array}$ & Malvaceae & Shimul & Root & $\begin{array}{l}\text { Leucorrhea, Parkinson's disease (body tremors). Powdered roots of } \\
\text { Salmalia malabarica, roots of Abroma augusta, tubers of Ipomoea } \\
\text { digitata, leaves of Piper longum, fruits of Terminalia chebula, fruits of } \\
\text { Terminalia bellirica, fruits of Phyllanthus emblica, whole plants of } \\
\text { Wedelia chinensis, whole plants of Tinospora cordifolia, seeds of } \\
\text { Syzygium cumini and seeds of Mangifera indica are mixed with honey. } \\
\text { Tablets made from the mixture are dried under the sun and taken orally } \\
\text { twice daily. }\end{array}$ \\
\hline 23 & Sida cordifolia $\mathrm{L}$. & Malvaceae & Brela & Whole plant & $\begin{array}{l}\text { Stoppage of urination. Juice obtained from crushed whole plant is taken } \\
\text { orally with honey. At the same time paste of whole plant of Sida } \\
\text { cordifolia and whole plant of Eichhornia crassipes is topically applied } \\
\text { to lower abdomen. }\end{array}$ \\
\hline
\end{tabular}




\begin{tabular}{|c|c|c|c|c|c|}
\hline 24 & Martynia anпua L. & Martyniaceae & Bagh thaba & Root & $\begin{array}{l}\text { Skin infection. Roots are crushed with fruits of Piper nigrum to obtain } \\
\text { juice, which is applied topically to affected areas. }\end{array}$ \\
\hline 25 & $\begin{array}{l}\text { Tinospora } \\
\text { cordifolia (Willd.) } \\
\text { Miers. }\end{array}$ & Menispermaceae & Gohonchi & Whole plant & See Salmalia malabarica. \\
\hline 26 & $\begin{array}{l}\text { Artocarpus } \\
\text { heterophyllus } \\
\text { Lam. }\end{array}$ & Moraceae & Kathal & Fruit & See Musa paradisiaca. \\
\hline 27 & $\begin{array}{l}\text { Musa paradisiaca } \\
\text { L. }\end{array}$ & Musaceae & Atia kola & Fruit & $\begin{array}{l}\text { Flatulence. Pills prepared from paste of fruits of Musa paradisiaca, } \\
\text { Artocarpus heterophyllus and Nigella sativa are taken orally, five pills in } \\
\text { the morning and five in the evening. }\end{array}$ \\
\hline 28 & $\begin{array}{l}\text { Myristica fragrans } \\
\text { Houtt. }\end{array}$ & Myristicaceae & Jayatri & Seed coat & See Carthamus tinctorius. \\
\hline 29 & $\begin{array}{l}\text { Syzygium cumini } \\
\text { (L.) Skeels }\end{array}$ & Myrtaceae & Jaam gach & Bark, seed & $\begin{array}{l}\text { See Holarrhena pubescens. } \\
\text { See Salmalia malabarica. }\end{array}$ \\
\hline 30 & $\begin{array}{l}\text { Helminthostachys } \\
\text { zeylanica }(\mathrm{L} .) \\
\text { Hook. }\end{array}$ & Ophioglossaceae & Ekbir ektir & Whole plant & $\begin{array}{l}\text { Piles. Paste of whole plant is mixed with sesame oil (oil obtained from } \\
\text { seeds of Sesamum indicum) and applied to anus. }\end{array}$ \\
\hline 31 & $\begin{array}{l}\text { Sesamum indicum } \\
\text { L. }\end{array}$ & Pedaliaceae & Til & Seed & See Helminostachys zeylanica. \\
\hline 32 & $\begin{array}{l}\text { Phyllanthus } \\
\text { emblica L. }\end{array}$ & Phyllanthaceae & Amloki & Fruit & See Salmalia malabarica. \\
\hline 33 & Piper betle L. & Piperaceae & Paan & Leaf & See Carthamus tinctorius. \\
\hline 34 & Piper cubeba L. & Piperaceae & Kabab chini & Fruit & See Carthamus tinctorius. \\
\hline 35 & Piper longum L. & Piperaceae & Pipul & Leaf & See Salmalia malabarica. \\
\hline 36 & Piper nigrum L. & Piperaceae & $\begin{array}{l}\text { Shada gol } \\
\text { morich }\end{array}$ & Fruit & $\begin{array}{l}\text { See Cynodon dactylon. } \\
\text { See Celsia coromandeliana. } \\
\text { See Martynia annua. }\end{array}$ \\
\hline 37 & $\begin{array}{l}\text { Plumbago } \\
\text { zeylanica } \mathrm{L} .\end{array}$ & Plumbaginaceae & Niltok chita & Whole plant & See Alocasia indica. \\
\hline 38 & $\begin{array}{l}\text { Cynodon dactylon } \\
\text { (L.) Pers. }\end{array}$ & Poaceae & Durba & Whole plant & $\begin{array}{l}\text { Anal bleeding, bleeding through the penis. Juice obtained from crushed } \\
\text { whole plant of Cynodon dactylon, two fruits of Piper nigrum, and whole } \\
\text { plants of Withania somnifera and Eichhornia crassipes is taken orally 2- } \\
3 \text { times daily. }\end{array}$ \\
\hline 39 & $\begin{array}{l}\text { Eichhornia } \\
\text { crassipes (Mart.) } \\
\text { Solms. }\end{array}$ & Pontederiaceae & $\begin{array}{l}\text { Kochuri } \\
\text { pana }\end{array}$ & Whole plant & $\begin{array}{l}\text { See Cynodon dactylon. } \\
\text { See Sida cordifolia. }\end{array}$ \\
\hline 40 & Nigella sativa $\mathrm{L}$. & Ranunculaceae & Kalo jira & Seed & $\begin{array}{l}\text { See Carthamus tinctorius. } \\
\text { See Musa paradisiaca. }\end{array}$ \\
\hline 41 & $\begin{array}{l}\text { Citrus aurantium } \\
\text { L. }\end{array}$ & Rutaceae & Kagji lebu & Fruit & See Tamarindus indica. \\
\hline 42 & $\begin{array}{l}\text { Celsia } \\
\text { coromandeliana } \\
\text { Vahl }\end{array}$ & Scrophulariaceae & Kukur muta & $\begin{array}{l}\text { Bottom part of } \\
\text { plant above } \\
\text { ground level }\end{array}$ & $\begin{array}{l}\text { Diarrhea. Bottom part of plant is made into a paste with fruits of Piper } \\
\text { nigrum and table salt, lightly warmed over fire and taken orally. }\end{array}$ \\
\hline 43 & $\begin{array}{l}\text { Nicotiana tabacum } \\
\text { L. }\end{array}$ & Solanaceae & Tanku & Whole plant & See Alocasia indica. \\
\hline 44 & $\begin{array}{l}\text { Withania } \\
\text { somnifera (L.) } \\
\text { Dunal }\end{array}$ & Solanaceae & $\begin{array}{l}\text { Ashwagandh } \\
\text { a }\end{array}$ & Whole plant & See Cynodon dactylon. \\
\hline 45 & $\begin{array}{l}\text { Abroma augusta } \\
\text { L. }\end{array}$ & Sterculiaceae & Olot komor & Root & $\begin{array}{l}\text { See Leea macrophylla. } \\
\text { See Salmalia malabarica. }\end{array}$ \\
\hline 46 & $\begin{array}{l}\text { Sterculia urens } \\
\text { Roxb. }\end{array}$ & Sterculiaceae & Katila & Gum & $\begin{array}{l}\text { Urinary tract stone. Pills are prepared from a mixture containing } 100 \mathrm{~g} \\
\text { gum from Sterculia urens, } 25 \mathrm{~g} \text { rhizome of Zingiber officinale, } 10 \mathrm{~g} \\
\text { sulfur, and } 100 \mathrm{~g} \text { misri (crystalline sugar) and taken orally. } \\
\text { Kidney, urinary tract, biliary stone. Gum from Sterculia urens is mixed } \\
\text { with camphor (a terpenoid compound found in the wood of the tree } \\
\text { Cinnamomum camphora), rhizome of Zingiber officinale and sulfur. } \\
\text { Tablets made from the mixture are taken orally. }\end{array}$ \\
\hline 47 & $\begin{array}{l}\text { Leea macrophylla } \\
\text { Roxb. ex Hornem. }\end{array}$ & Vitaceae & Hasti polash & $\begin{array}{l}\text { Leaf, root, } \\
\text { flower }\end{array}$ & $\begin{array}{l}\text { Bone fracture. Paste of leaf and root of Leea macrophylla and root of } \\
\text { Abroma augusta is mixed with chicken egg and applied topically on the } \\
\text { fractured area. } \\
\text { To increase sex ability. } 50 \mathrm{~g} \text { of Leea macrophylla powdered flowers and } \\
500 \mathrm{~g} \text { of Abroma augusta powdered roots are mixed together. Pills } \\
\text { prepared from the powdered mixture are taken orally. } \\
\text { See Wedelia chinensis. } \\
\text { See Carthamus tinctorius. }\end{array}$ \\
\hline 48 & $\begin{array}{l}\text { Zingiber officinale } \\
\text { Roscoe }\end{array}$ & Zingiberaceae & Ada & Rhizome & $\begin{array}{l}\text { See Tamarindus indica. } \\
\text { See Sterculia urens. } \\
\text { See Justicia adhatoda. } \\
\text { See Sterculia urens. }\end{array}$ \\
\hline
\end{tabular}




\section{CONCLUSION}

The plants and formulations used by the FMP merit scientific research towards possible discovery of new drugs.

Financial support and sponsorship: NIL.

Conflict of Interests: There are no conflicts of interest.

\section{REFERENCES}

Ayyanar M, Subash-Babu P. Syzygium cumini (L.) Skeels: A review of its phytochemical constituents and traditional uses. Asian Pac J Trop Biomed, 2012; 2: 240-246.

Bora NS, Kakoti B, Gogoi B, Goswami AK. Ethno-medicinal claims, phytochemistry and pharmacology of Spondias pinnata: A review. Int J Pharmaceut Sci Res, 2014; 5: 1138-1145.

Gupta YK, Katyal J, Kumar G, Mehla J, Katiyar CK, Sharma N, Yadav S. Evaluation of antitussive activity of formulations with herbal extracts in sulphur dioxide $\left(\mathrm{SO}_{2}\right)$ induced cough model in mice. Indian $\mathrm{J}$ Physion Pharmacol, 2009; 53: 61-66.

Kundu MK, Alam MM, Arefin Z, Yasmin S, Yeasmin S, Islam E, Rahmatullah M. Phytotherapeutic practices of a folk medicinal practitioner of Jhenaidah district, Bangladesh. World J Pharm Pharmaceut Sci, 2016; 5: 127-136.

Malhotra S, Singh AP. Medicinal properties of ginger (Zingiber officinale Rosc.). Nat Prod Radiance, 2003; 2: 296-301.

Martin GJ. Ethnobotany: a 'People and Plants' Conservation Manual, Chapman and Hall, London, 1995, pp268.

Maundu P. Methodology for collecting and sharing indigenous knowledge: a case study. Indigenous Knowledge and Development Monitor, 1995; 3: 3-5.

Mukherjee S, Dey A, Das T. In vitro antibacterial activity of nhexane fraction of methanolic extract of Alstonia scholaris L. R.Br. stem bark against some multidrug resistant human pathogenic bacteria. Eur J Med Plants, 2012; 2: 1-10.
Rahmatullah M, Biswas KR. Traditional medicinal practices of a Sardar healer of the Sardar (Dhangor) community of Bangladesh. J Altern Complement Med, 2012; 18: 10-19.

Rahmatullah M, Hasan A, Parvin W, Moniruzzaman M, Khatun Z, Jahan FI, Jahan R. Medicinal plants and formulations used by the Soren clan of the Santal tribe in Rajshahi district, Bangladesh for treatment of various ailments. Afr J Tradit Complement Alternat Med, 2012a; 9: 350359.

Rahmatullah M, Khatun Z, Hasan A, Parvin W, Moniruzzaman M, Khatun A, Mahal MJ, Bhuiyan MSA, Mou SM, Jahan R. Survey and scientific evaluation of medicinal plants used by the Pahan and Teli tribal communities of Natore district, Bangladesh. Afr J Tradit Complement Alternat Med 2012b; 9: 366-373.

Rahmatullah M, Azam MNK, Khatun Z, Seraj S, Islam F, Rahman MA, Jahan S, Aziz MS, Jahan R. Medicinal plants used for treatment of diabetes by the Marakh sect of the Garo tribe living in Mymensingh district, Bangladesh. Afr J Tradit Complement Alternat Med, 2012; 9: 380-385.

Sharma DK, Gupta VK, Kumar S, Joshi V, Mandal RSK, Prakash AGB, Singh M. Evaluation of antidiarrheal activity of ethanolic extract of Holarrhena antidysenterica seeds in rats. Vet World, 2015; 8: 1392-1395.

Zaman T, Keya KF, Akter S, Sagar MH, Khan MS, Bhuiyan MB, Malek I, Rahmatullah M. Plants as medicines: documentation of medicinal plants used by a Khasia tribal practitioner in Habiganj district, Bangladesh. World J Pharm Pharmaceut Sci, 2015; 4: 55-63.

\section{How to cite this article:}

Shah R, Islam M, Rabbi F, Shova NA, Akter A, Akter H, Ahmed I, Islam E, Rahmatullah M. Phytotherapeutic practices of a folk medicinal practitioner in Dinajpur district, Bangladesh. J App Pharm Sci, 2017; 7 (05): 161-165. 